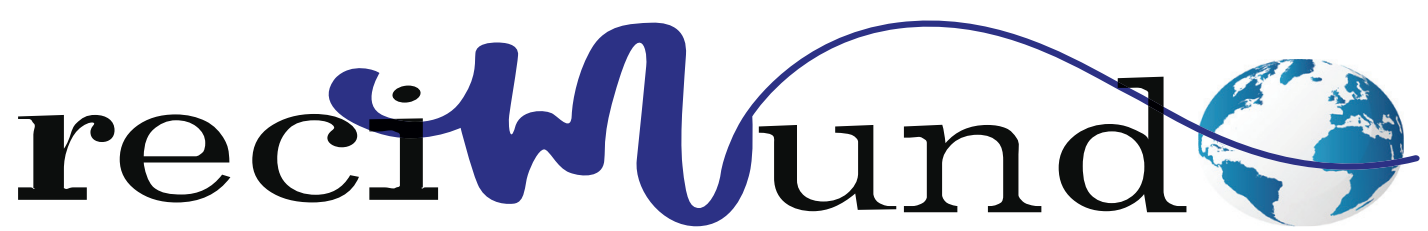

Revista Científica Mundo de la Investigación y el Conocimiento

Dol: 10.26820/recimundo/4.(2).mayo.2020.195-208

URL: http://recimundo.com/index.php/es/article/view/836

EDITORIAL: Saberes del Conocimiento

REVISTA: RECIMUNDO

ISSN: 2588-073X

TIPO DE INVESTIGACIÓN: Artículo de Revisión

Código UNESCO: 58 Pedagogía; 5801

Teoría y Métodos Educativos; 5801.07 Métodos Pedagógicos

PAGINAS: 195-208

\title{
Importance of applying operational methodological techniques during the period of teaching - learning English in University undergraduate
}

Importancia de aplicar técnicas metodológicas operativas durante el período de enseñanza - aprender ingles en la universidad

Importância da aplicação de técnicas metodológicas operacionais durante 0 período de ensino - aprendendo inglês na graduação da universidade

Jacqueline Jeaneen Veliz Blacio ${ }^{1}$

RECIBIDO: 15/03/2020 ACEPTADO: 20/03/2020 PUBLICADO: 20/05/2020

1. Licenciada en Lengua Inglesa, Graduada en la Universidad Católica de Guayaquil; Certificada Academia Internacional en la Niveles C1 y B2; Graduada y Titulada en Academias de Inglés Centro Ecuatoriano Norteamericano (C.E.N) y Centro Politécnico de Inglés (COPEI) Universidad de Guayaquil; Docente de la Universidad de Guayaquil; Guayaquil, Ecuador; jeaneenveliz94@hotmail.com; (D) https://orcid.org/0000-0002-0071-3399

CORRESPONDENCIA

Jacqueline Jeaneen Veliz Blacio

jeaneenveliz94@hotmail.com

Guayaquil, Ecuador

○ RECIMUNDO; Editorial Saberes del Conocimiento, 2020 


\section{RESUMEN}

El aprendizaje en la educación universitaria debe garantizar que los estudiantes aprendan a estudiar y a investigar, potenciar el deseo de saber cada día más y mejor. Debe formar a profesionales competentes, es decir, desarrollarlos integralmente en diferentes órdenes: intelectual, social, ético, estético, político-ideológico. La asignatura inglés se desarrolla a través de los siguientes métodos y técnicas generales, en muchas universidades: clase magistral, realización de trabajos individuales, debates, lectura sobre páginas web relacionadas, tutorías personalizadas, ejercicios y actividades prácticas. La nueva estrategia de idioma inglés en la educación superior está orientada al logro de una cultura de formación en lenguas extranjeras por parte de estudiantes y profesores. Contempla la implementación de métodos y procedimientos didácticos propios de una enseñanza-aprendizaje. El uso de tecnología puede mejorar la calidad y ofrecer una solución de corto plazo a la falta de profesores con niveles altos de dominio del inglés. Algunas herramientas que facilitan el aprendizaje: Skype, foros, blocks, YouTube, entre otros. Por lo tanto, es relevante mencionar que las TIC constituyen un instrumento de ayuda al personal docente a planear y desarrollar sus lecciones. Sin duda, la integración de las TIC también implica costos y problemáticas, pero el cambio resulta absolutamente imprescindible, ya que estamos en una nueva era en la que las TIC se constituyen en un instrumento poderoso y versátil que permiten el desarrollo de nuevas destrezas y formas de construcción del conocimiento.). Se aplicó una metodología descriptiva, con un enfoque documental, es decir, revisar fuentes disponibles en la red, con contenido oportuno y relevante para dar respuesta a lo tratado en el presente artículo.

Palabras clave: Estrategias, investigación, aprendizaje, tecnología, TIC, foros, internet.

\section{ABSTRACT}

Learning in university education must guarantee that students learn to study and research, to enhance the desire to know more and better every day. It must train competent professionals, develop them integrally in different orders: intellectual, social, ethical, aesthetic, political-ideological. The English subject is developed through the following general methods and techniques, in many universities: master class, individual work, debates, reading on related web pages, personalized tutorials, exercises and practical activities. The new English language strategy in higher education is aimed at achieving a culture of training in foreign languages by students and teachers. It contemplates the implementation of didactic methods and procedures typical of a teaching-learning. The use of technology can improve quality and offer a short-term solution to the lack of teachers with high levels of English proficiency. Some tools that facilitate learning: Skype, forums, blogs, YouTube, among others. Therefore, it is relevant to mention that ICT constitutes an instrument to help teaching staff to plan and develop their lessons. No doubt, the integration of ICTs also implies costs and problems, but the change is absolutely essential, since we are in a new era in which ICTs are a powerful and versatile instrument that allow the development of new skills and forms of knowledge construction. A descriptive methodology was applied.

Keywords: Strategies, research, learning, technology, ICT, forums, internet.

\section{RESUMO}

O aprendizado no ensino universitário deve garantir que os alunos aprendam a estudar e pesquisar, para aumentar o desejo de saber mais e melhor todos os dias. Deve formar profissionais competentes, desenvolvê-los integralmente em diferentes ordens: intelectual, social, ética, estética, político-ideológica. O assunto em inglês é desenvolvido através dos seguintes métodos e técnicas gerais, em muitas universidades: master class, trabalho individual, debates, leitura em páginas relacionadas, tutoriais personalizados, exercícios e atividades práticas. A nova estratégia de língua inglesa no ensino superior visa alcançar uma cultura de treinamento em línguas estrangeiras por estudantes e professores. Contempla a implementação de métodos e procedimentos didáticos típicos de um ensino-aprendizagem. O uso da tecnologia pode melhorar a qualidade e oferecer uma solução de curto prazo para a falta de professores com altos níveis de proficiência em inglês. Algumas ferramentas que facilitam o aprendizado: Skype, fóruns, blogs, YouTube, entre outras. Portanto, é relevante mencionar que as TIC constituem um instrumento para ajudar os professores a planejar e desenvolver suas lições. Sem dúvida, a integração das TICs também implica custos e problemas, mas a mudança é absolutamente essencial, pois estamos em uma nova era na qual as TICs são um instrumento poderoso e versátil que permite o desenvolvimento de novas habilidades e formas de construção do conhecimento. Foi aplicada uma metodologia descritiva.

Palavras-chave: Estratégias, pesquisa, aprendizado, tecnologia, TIC, fóruns, internet. 


\section{Introducción}

Teaching-learning models have undergone significant transformations in recent decades, which has allowed them to evolve: from educational models focused on teaching to models aimed at learning, and the change in teacher's profiles and students.

The new educational models demand that teachers transform their role from exhibitors of knowledge to monitors of learning, and students from spectators of teaching process to members, participants, with proposals and critics in the construction of their own knowledge. Likewise, the study and generation of innovations in teaching-learning strategies field constitute priority lines of research to adapt the knowledge base of educational sciences to current challenges (A. Collaguazo Potosi, 2011).

During the second language learning process, the teaching staff is supported by activities that only involve writing and oral repetitions as part of their methodological strategy. However, these are often perceived by students as boring or unmotivating. That is why the implementation of oral, written and listening activities must be innovative and motivated to students in order to explore and develop their linguistic abilities to learn the target language, beyond a program or qualification.

Education in today's world needs to be increasingly efficient. This is one of the great challenges of the contemporary era. From the University it is necessary to educate the young people, with the best values and the most advanced advances in science; promote the development of attitudes to learn safely and independently. However, much of these inefficient results are due to the use of worn techniques, it is convenient to innovate the university student's teaching of English as will be explained below in this article.

\section{Methodology}

This research is directed to study "The importance of applying operational methodological techniques during the period of teaching - learning English in the university undergraduate". To carry it out, a descriptive methodology was used, with a documentary approach, reviewing sources available on network, whose content is current, published in science journals, available in Google Scholar, as closely as possible to the purpose of the writing, with timely content and relevant from a scientific point of view to respond to what is discussed in this article to serve as inspiration for other projects. They can be studied at the end, in the bibliography.

\section{Results}

Learning in university education must guarantee that students learn to study and research, to enhance the desire to know more and better every day. It must train competent professionals, develop them integrally in different orders: intellectual, social, ethical, aesthetic, political-ideological. Difficulties in learning on students who start Universities to present gaps and little command of content that must have expired at the previous levels.

It is the result, to a large extent, to application of traditional teaching methods by teachers and the little incorporation of students into an active role in learning.

Regarding teaching and learning strategies, Pozo (1996) states:

The acquisition of learning strategies is defined as the appropriation of integrated sequences of procedures or activities that are chosen with the purpose of facilitating the acquisition or storage and / or the use of information or knowledge; and that these activities or proce-

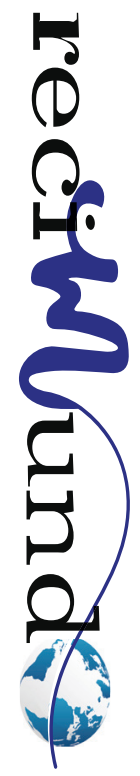


dures that are part of the strategies are usually called study techniques or habits.(S. Ponce Merino, 2017)

The procedures can become automated and mechanically applied to similar situations already known; But when faced with uncertain situations, it requires the ability to analyze them and make strategic decisions about the most appropriate procedure to deal with them successfully.
According to Pozo (1996) "metacognitive capacity as the degree of consciousness, regulation, explanation and externalization that is exerted on our mental actions intervenes in strategic learning"(Mastro, 2000), which allows planning, controlling and evaluating the mental decisions put in place to learn content or solve a problem. The following scheme summarizes the relationship between the terms explained above:

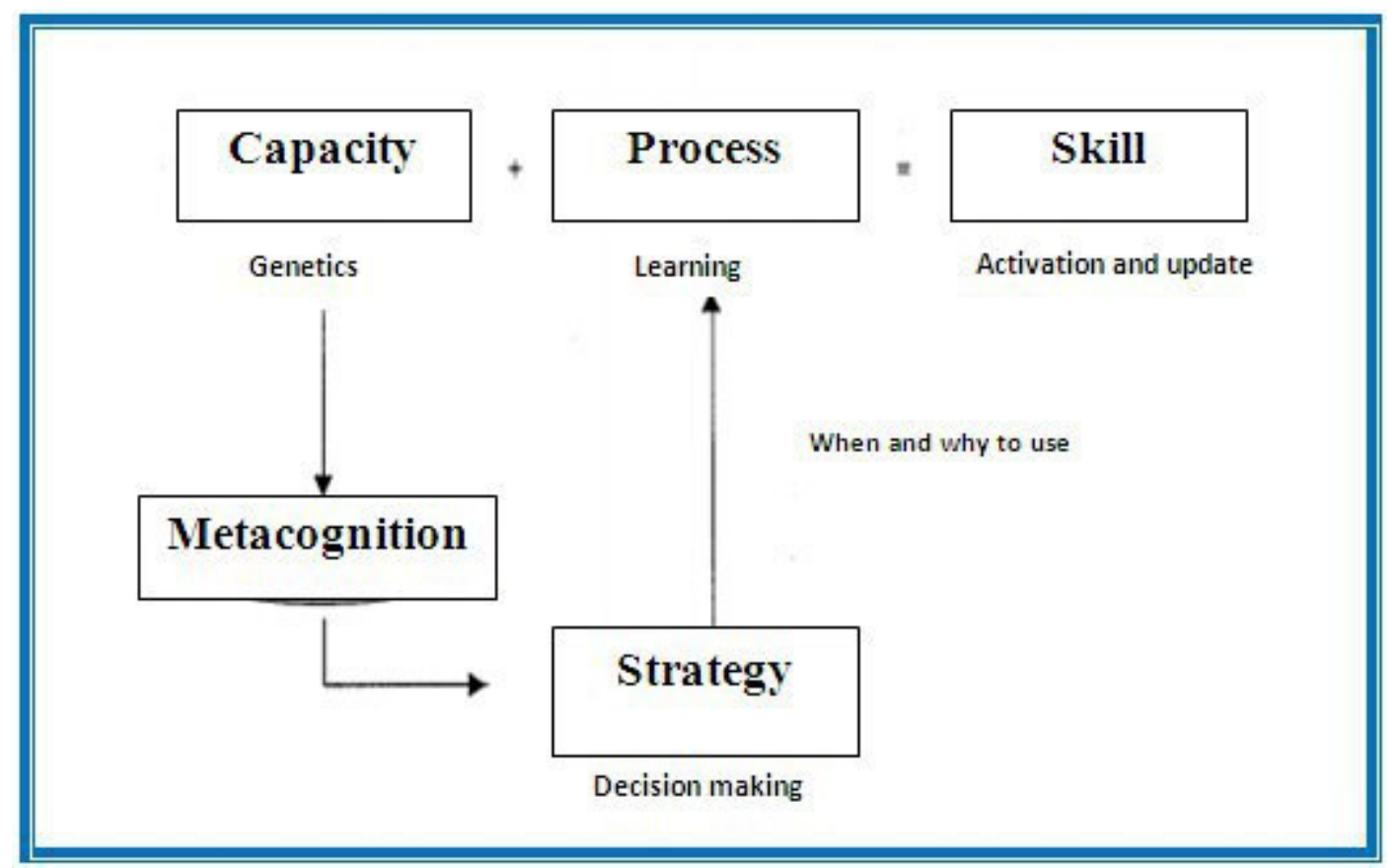

Figure 1. Metacognitive capacity

Source: (Mastro, 2000)

Another author exposes on the subject, Monereo (1996) that a strategic action is characterized by being (Saneugenio, 2001):

Conscious or cognitive goal: allows to become aware of the particular cognitive functioning, facilitates its control and regulation.

Adaptable: it adapts to the variable conditions on which decisions must be made planning the course of action to be followed; controlling and modifying the process; and evaluating the level of achievement obtained.
Effective: a balance must be struck between the cost - benefit of the strategies used and the achievement achieved.

Sophisticated: the repetition in the use of a strategy will improve the action to achieve a better quality in the achievements produced.

Within procedures aimed at learning to learn, those related to information processing gain strength. In this regard, Pozo proposes to classify the procedural contents prioritizing the processes of acquisition, interpretation, analysis, understanding, organization and 
communication of information, which is summarized in the following table:

Table 1. Procedures aimed at learning

\begin{tabular}{|c|c|}
\hline \multirow{4}{*}{ 1- ACQUISITION OF INFORMATION } & A) Observation \\
\hline & B) Selection of information \\
\hline & C) Search and collection of information \\
\hline & $\begin{array}{l}\text { D) Review and memorization of } \\
\text { information }\end{array}$ \\
\hline \multirow{2}{*}{$\begin{array}{ll}\text { 2- } & \text { INTERPRETATION OF } \\
& \text { INFORMATION }\end{array}$} & A) Decoding or translation of information \\
\hline & B) Use of models to interpret \\
\hline \multirow{3}{*}{$\begin{array}{l}\text { 3- } \text { INFORMATION ANALYSIS AND } \\
\text { MAKING INFERENCES }\end{array}$} & A) Analysis and comparison of information \\
\hline & B) Reasoning strategies \\
\hline & C) Research or problem solving activities \\
\hline \multirow{3}{*}{$\begin{array}{l}\text { 4- } \\
\text { UNDERSTANDING AND } \\
\text { CONCEPTUAL ORGANIZATION OF } \\
\text { INFORMATION }\end{array}$} & A) Speech comprehension (written / oral) \\
\hline & B) Establishing conceptual relationships \\
\hline & C) Conceptual organization \\
\hline \multirow{3}{*}{ 5- COMUNICATION OF INFORMATION } & A) Oral expression \\
\hline & B) Written expression \\
\hline & C) Other types of expression \\
\hline
\end{tabular}

Source: (Mastro, 2000)

Teaching has focused on a set of procedures that the student must automate to the maximum to convert them into study habits that are acquired automatically, applied in various situations. This type of teaching does not present a close relationship between the strategies and the content, making it difficult to transfer them to other subjects and learning contexts. Learning strategies should be taught considering the specific learning contexts and content.

The English subject is developed through the following general methods and techniques, in many universities according to the characteristics of the subject (Reyes, 2017):

- Master class: the teacher of the subject exposes and explains to the students the main contents of it.

- Completion of individual assignments: the student prepares various assignments based on the guidelines provided.

- Debates: allows the student to participate and encourage them to be up-to-date in relation to the matter or topic in question.

- Reading on related web pages.

- Personalized tutorials: a time for the student to ask questions about the subject.

- Exercises and practical activities: it allows them to acquire the consequent competences, preparation and presentation of a practical class.

- Written exams or evaluations.

The new English language strategy in higher education is aimed at achieving a culture of training in foreign languages by students and teachers. It contemplates the implementation of didactic methods and procedures typical of a teaching-learning

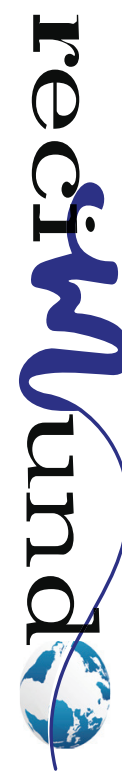


by linguistic levels and contains, in turn, access to information, learning from the application of linguistic, interactive, personal and professional resources that previously were not required but require of deep scientific thought.

The conception and implementation of this strategy is based on the following essential premises (C. Rey Rivas, 2017):

- The assumption of new roles in the management of the teaching-learning process of foreign languages.

- The achievement of a culture of training in foreign languages, from didactic methods and procedures typical of a teaching-learning by linguistic levels.

- The accumulated experience and the scientific-methodological preparation of the teachers.

- The sustained methodological work of teachers to determine the needs for training in foreign languages according to current trends.

- The conviction, by the teachers, of the need to accept and implement the most current parameters in the teaching-learning process of the English language.

\section{Learning English and ICT as a tool}

In higher education these systems present great opportunities for teachers especially, for students in terms of accessibility, flexibility of time, space, rhythm, schedules, etc. and in some cases of costs (E. Hernández, 2014). These environments become increasingly important, because to be active in the new social space requires new knowledge and skills that must be learned in educational processes.

The use of semi-face-to-face learning methods allows technology to help the teacher from the classroom to provide quality English lessons. Research shows According to Pereira and Ramírez "the potential impact of semi-face-to-face learning methodology on the command of English and the motivation of students to learn" (Ramírez, 2008). They explain that students were more interested in the subject and improved their English language skills when technology was incorporated into classroom instruction.

The use of technology can improve quality and offer a short-term solution to the lack of teachers with high levels of English proficiency. In Peru, "the application of the semi-face-to-face learning methodology also implies specialized software for teaching English"(Fiszbein, 2017). Some of the activities suggested below exploit ICT as a central axis in the fulfillment of objectives and the development of language skills(G. Pizarro Chacón, 2013):

- Skype: it is one of the most used technological tools by native and non-native speakers of a language. It is useful as a method of establishing links between individuals from different countries whose purpose is to learn and practice the target language orally. Also, it is a way of learning not only the language in an informal way, but also allows us to understand and resort to colloquial phrases of a language.

- Forums: the use of forums as a tool to be able to discuss in writing about topics related to the course is interesting for students. It helps the use of grammar in a contextualized form and allows the exchange of ideas between the different participants.

- Blogs: Students are able to interact with native speakers or second language learners. Students will be able to use a more informal writing style according to group, slang, or dialect variation.

- Movie / video creators: Allows students both group and individual to make movies or videos. It allows the development of written and oral skills, when writing dialogues or making recordings. Students will be able to listen to dialogues spoken in different dialects, allowing 
their dialectal variability and general culture about speakers of the English language to be expanded.

- YouTube: The advantages of YouTube are allowing a message in the target language to be transmitted in a short time and be received by a large number of network users. Thanks to this tool, students can develop skills in the use of body language, conversation techniques, share the result of an investigation and share problems that second language learners face in their learning process, reaching a more updated environment of use. of the target language and its learning process.

\section{Advantages and disadvantages of using ICT}

There are several advantages in the application of ICT for teaching a second language. Free software and computer equipment are promoted by international organizations, such as UNESCO, in all countries of the world. The objective is to bridge the gap between poor countries and those with great wealth and further development. Morán (2012) adds "advantages such as the way in which the levels of knowledge are acquired and the innovative pedagogical models that they stimulate" (Siboney, 2013).

However, some disadvantages are: the tension and ignorance of the learning facilitators regarding the use of ICT, and the production of content. Analyzing the advantages and disadvantages of the proposals in this article we have: 


\section{Skype}

\section{Advantage}

It is easy and quick to install.

$\checkmark$ Free phone calls to other Skype users anywhere in the world.

$\checkmark$ Skype works on most computers: Windows, Mac OS X, Linux and Pocket Out.

\section{Disadvantages}

Having unwanted contacts.

$\checkmark$ Voicemail is not free.

$\checkmark$ Obtain a virus when downloading by not obtaining it from the appropriate page.

$\checkmark$ Sometimes poor sound and video resolution occurs

\section{Forums}

\section{Advantage}

$\checkmark \quad$ It is flexible.

$\checkmark$ Facilitates the participation of introverts.

$\checkmark$ Facilitates group learning.

$\checkmark$ Generate a completed exchange log.

$\checkmark$ Promote motivation.

\section{Disadvantages}

Loss of non-verbal communication.

$\checkmark$ Overload of information. Not all have a network connection.

$\checkmark$ The tutor cannot ensure that the messages sent are read by the student.

$\checkmark$ Not all students have the ability to express their ideas in writing in a concise manner. 


\section{Blogs}

\section{Advantage}

$\checkmark$ Optimization of resources and renewal of work methodologies.

$\checkmark$ Relationship with the world, possibility of finding similar collaborators, informal and shared continuous training.

$\checkmark$ Revaluation of the professional image of the teacher.

$\checkmark$ Excellent gateway to implement ICT, due to the simplicity of use, learning and development of varied competences.

\section{Disadvantages}

By themselves it does not promote meaningful learning, it is necessary to contemplate it in a context that promotes and guides the achievement of the expected objectives.

$\checkmark$ The evaluation of progress requires significant teacher time.

$\checkmark$ It brings the trap of copying and pasting any available content, reducing creativity, originality.

$\checkmark$ Wear on the shape and not the bottom.

\section{Movie - Video creator}

\section{Advantage}

$\checkmark$ It is free for Windows users.

$\checkmark$ It is useful for home movies, slide shows, and music.

$\checkmark$ The effects are varied and we can play with them to make the videos more original.

\section{Disadvantages}

$\checkmark$ It hangs with large files.

$\checkmark$ It only exports in wmv format.

$\checkmark$ The typography of the texts is not modern in relation to other available formats.

$\checkmark$ The animation effects look pretty basic. 


\section{Youtube}

Advantage

$\checkmark$ Create communities through subscriptions.

$\checkmark$ Establish alliances with YouTube to own a private channel to broadcast your own material.

$\checkmark$ The process of uploading videos to your channel is simple and fast, it accepts most of the most used video formats.

$\checkmark \quad$ It has a large storage capacity, you can upload videos without space problems.

$\checkmark$ Viewing from any device, laptop, smartphone, tablet, etc,

$\checkmark$ The videos uploaded to your channel can be viewed worldwide.

Therefore, it is relevant to mention that ICT constitutes an instrument to help teaching staff to plan and develop their lessons. This is not the only element available for teaching a second language; the technological resource must be adapted according to the social, human and methodological context.

There is no doubt, the integration of ICTs also implies costs and problems, but the change is absolutely essential, since we are in a new era in which ICTs are a powerful and versatile instrument that allow the development of new skills and forms. of knowledge construction.

\section{E-learning}

Also called electronic learning, digital learning or online learning, it is characterized by technological and computer and communications convergence, considering the peda-

\section{Disadvantages}

Comments cannot be blocked.

It is limited to 10 minutes of playback, copyright and privacy.

$\checkmark$ They can alter the actual facts of an event.

$\checkmark$ Anyone can see all the videos that are uploaded.

$\checkmark$ Videos can be blocked if people dislike them.

gogical criteria that determine the selection of technology, distance delivery formats that these modalities use. Some authors such as García Aretio point out:

E-learning is the natural evolution of distance education and is considered an alternative to traditional teaching when students, due to specific circumstances, cannot follow face-to-face training and decide to receive it through ICT. It must be understood as a form of study in which the protagonist is the student and whose success will depend largely on the human support behind it. (E. Hernández, 2014)

This method has proven effective for certain situations with a population with adequate characteristics to carry out learning based on this model, however it has its limitations. It is a suitable model for distance education systems, little or less effective when it co- 
mes to traditional universities, which have wanted to convert their programs into courses based on digital learning.

Therefore, in an educational context characterized by the presence of technologies, a new conception of academic training focused on student learning and a revaluation of the role of the teacher aimed at improving the quality of education is appropriate. In this sense, it is one of the training strategies and modalities that has aroused the most interest in recent times in universities. Its success in the educational field must be due to: making training scenarios more flexible, creating training environments adapted to the characteristics and needs of the student, ease of introducing and renewing teaching content and materials, is highly interactive.

\section{English in Latin America}

The international business community recognizes the increasing importance of English proficiency for international collaboration and success in globalization. Many multinational companies require that English be the common corporate language, showing that English has established itself as the lingua franca in the business world(Fiszbein, 2017).

A study carried out in 2014 revealed that $87 \%$ of the human resources managers of multinational companies in thirteen countries (considering three Latin American nations: Brazil, Chile and Mexico) stated that English proficiency is important for their employees. (Fiszbein, 2017).

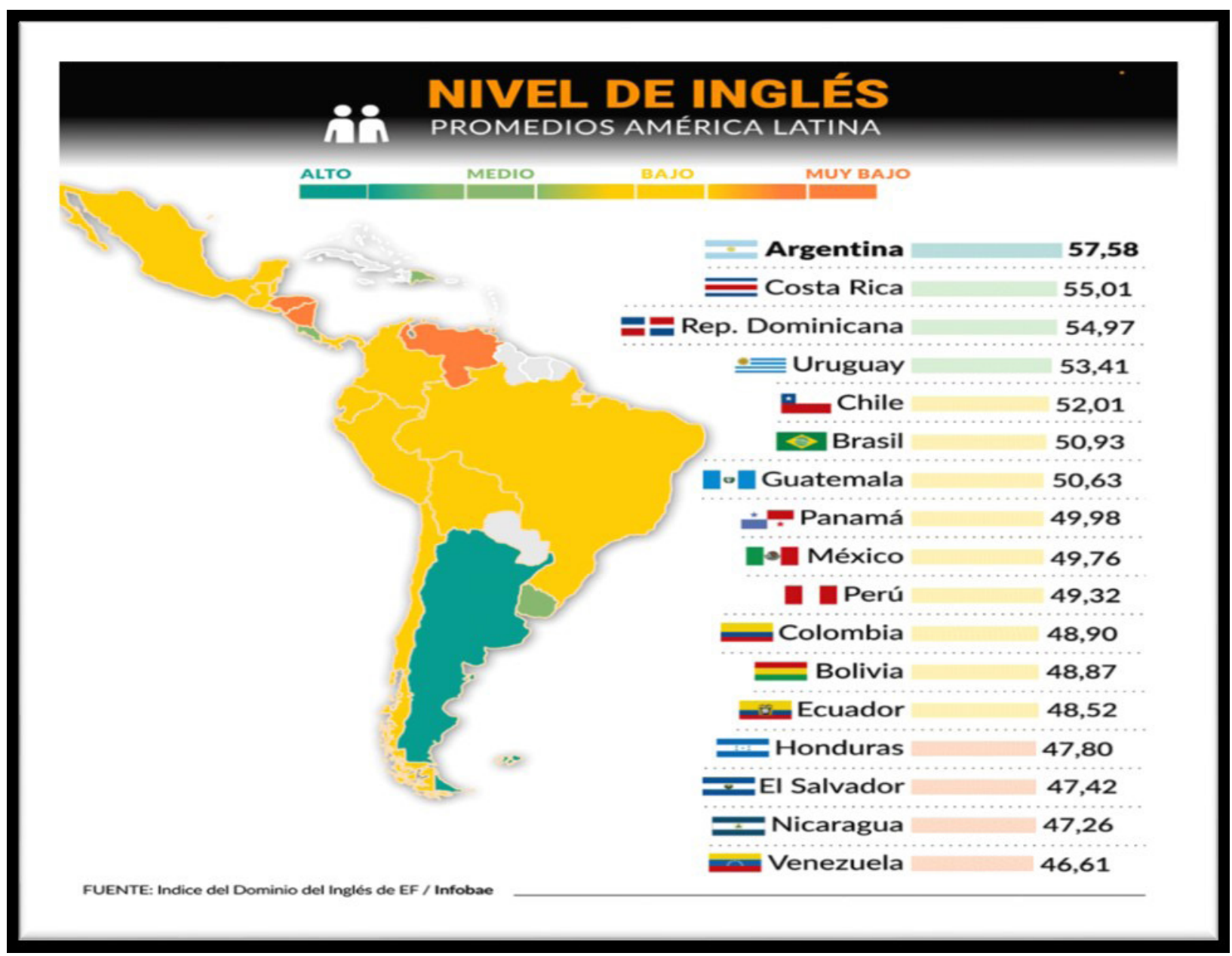

Figure 2. Average level of English in Latin America

Source: (INFOBAE, 2018) 
Improving English language learning in Latin America will require a comprehensive policy framework that guides actions and investments in the education system. The mere existence of a policy is not sufficient to determine its suitability, the degree of its implementation or its impact on learning outcomes. Additionally, if policies are considered to be tools for management and strategic direction, they provide a valuable perspective for understanding strengths and weaknesses at the systemic level.

\section{Teaching English in Ecuador}

Language teaching in Ecuador today is aimed at capturing the vision of learning from a communicative vision of language, that is why teachers must organize the teaching-learning process in a way that allows students to participate in meaningful interaction and communication as they perform tasks and exercises, they expand their linguistic resources and observe how language is used in interpersonal exchange in a meaningful way.

In Ecuador, the standards that must be met according to the CEFR. The reality is that the level of language proficiency is still below the established levels, in terms of language use. According to the last Report available in 2015 carried out by Education First (EF), Ecuador occupies the 38th position among 70 countries(Y. Castro, 2017). There are several reasons why Ecuador has not performed successfully in these studies.(BBC World, 2015):

- Internet connectivity.

- The ease of trading index in the country; volume of commercial and financial activity.

- Little improvement in its education system, the government or other related entity should invest in public education and training of teachers in English to ensure a solid level in the language.

\section{Conclusion}

Teaching design is a primary tool for achieving second language learning success. The implementation of technological programs will bring innovative, positive changes in the programs that are applied in the different careers of language teaching. The use of language laboratories, interactive packages, distance help through specialized programs or other support material will awaken the desire to learn a second language and will provide effective and attractive teaching strategies for both teachers and students.

This implies that the classroom will go from being a place where knowledge is provided in a vertical way, to a joint environment for teachers as students, they will learn to interact and develop skills. The teaching staff will be able to innovate their teaching strategies through the planning of classes that will reach the development: auditory, oral and written progressively enhanced.

Virtual Education can become a transforming factor within higher education, an instrument to improve its coverage, quality, relevance and equity of access, because it can serve a growing population of students, more socially and culturally diversified, a society increasingly dynamic and changing.

In addition to this, current students, especially those under the age of 30 , have an innate ability with technology, which is part of their daily lives, teachers must innovate teaching strategies, taking advantage of all the technological potential that we have at our disposal, with in order to improve the quality of education, achieve greater inclusion in better jobs and opportunities for students.

The results do not fall only on university teachers but at all educational and training levels, for example, a student who does not read appropriately, nor handle study techniques in their mother tongue, will hardly be 


\section{IMPORTANCE OF APPLYING OPERATIONAL METHODOLOGICAL TECHNIQUES DURING THE PERIOD OF TEACHING - LEARNING ENGLISH IN UNIVERSITY UNDERGRADUATE}

able to easily grasp another language. It is in the foundations or early education where the pillars of good training are founded. It is the responsibility of the universities to develop and apply all the pertinent strategies to improve the student's interest in deepening and mastering another language, in this case English.

Some countries assess students' English proficiency using optional tests, therefore not all students are tested, not even a representative sample. The optional nature of these exams results in a biased result of English proficiency, as the examinees self-select. Ensuring continuity allows a program to reach a maximum number of beneficiaries and achieve long-term results. Those programs also need to be updated to ensure they are on the right track and continually improving. Effective teachers are essential to facilitate learning and raise the level of English proficiency.

\section{Bibliography}

A. Collaguazo Potosi, M. A. (2011). Técnicas metodológicas para desarrollar la destreza de hablar en ingles en los estudiantes de segundo a octavo semestre de la especialidad de ingles de la FECYT de la Universidad Técnica del Norte durante el año lectivo 2008-2009. Universidad Técnica del Norte. Obtenido de http://repositorio.utn.edu.ec/ handle/123456789/2082

BBC Mundo. (11 de Febrero de 2015). Ecuador tiene 'nivel bajo de inglés', según informe de Education First. Índice de Aptitud en Inglés (EF EPI).

C. Rey Rivas, Y. T. (Agosto de 2017). Experiencias y resultados preliminares sobre la nueva estrategia de idioma inglés para la educación superior en la Universidad de Orien. Medisan, 21(9). Obtenido de http://scielo.sld.cu/pdf/san/v21n9/san14219. pdf

E. Hernández, A. B. (2014). EL B-LEARNING COMO ESTRATEGIA METODOLÓGICA PARA MEJORAR EL PROCESO DE ENSEÑANZA-APRENDIZAJE DE LOS ESTUDIANTES DE INGLÉS DE LA MODALIDAD SEMIPRESENCIAL DEL DEPARTAMENTO ESPECIALIZADO DE IDIOMAS UNIVERSIDAD TÉCNICA DE AMBATO. Obtenido de UNIVERSIDAD COMPLUTENSE DE MADRID: https://eprints. ucm.es/29610/1/T35913.pdf
Fiszbein, K. C. (2017). El aprendizaje del inglés en América Latina. EnEl aprendizaje del inglés en América Latina (pág. 88). Pearson. Obtenido de www. thedialogue.org/wp-content/uploads/2017/09/ El-aprendizaje-del-inglés-en-América-Latina-1.pdf

G. Pizarro Chacón, D. C. (Septiembre de 2013). Las TIC: Una herramienta tecnológica para el desarrollo de las competencias lingüísticas en estudiantes universitarios de una segunda lengua. Educare, 17(3). Obtenido de https://www. scielo.sa.cr/scielo.php?script=sci_arttext\&pi$d=$ S1409-42582013000300013

INFOBAE. (01 de Noviembre de 2018). INFOBAE. Obtenido de Indice del dominio del inglés de EF.: https://www.infobae.com/educacion/2018/11/01/ el-nivel-de-ingles-de-los-argentinos-volvio-a-seralto-y-se-consolida-como-el-mejor-de-latinoameri$\mathrm{cal}$

Mastro, C. d. (Septiembre de 2000). APRENDER A APRENDER: UNA APROXIMACION SOBRE EL USO CONSCIENTE E INTENCIONAL DE ESTRATEGIAS. Educación, 9(18), 217 - 237. Obtenido de www.dialnet-AprenderAAprender-5056813.pdf

Ramírez, S. P. (2008). USO DE ESTRATEGIAS METACOGNITIVAS DE ESTUDIANTES DE INGLÉS EN CURSO PRE-UNIVERSITARIO. Revista de Pedagogía, 29(85), 291 - 313. Obtenido de https://www. redalyc.org/pdf/659/65911809005.pdf

Reyes, N. S. (2017). Propuesta metodológica para el aprendizaje del inglés en la Universidad Tecnológica Equinoccial con el uso de las Tic. . Obtenido de Universidad de Extremadura: http://dehesa.unex. es/bitstream/handle/10662/6073/TDUEX_2017_ Salgado_Reyes.pdf?sequence $=1$ \&isAllowed =y

S. Ponce Merino, M. P. (Diciembre de 2017). Técnicas de estudio para contribuir el aprendizaje desarrollador del idioma inglés en la educación superior. Espirales Revista Multidisciplinaria de Investigación , 1(11). Obtenido de http://www.revistaespirales.com/index.php/es/article/view/192/142

Saneugenio, A. (2001). El Aprendizaje Estratégico. Docencla Universitarla, II(2), 105 - 109. Obtenido de http://www.ucv.ve/fileadmin/user_upload/sadpro/Documentos/docencia_vol2_n2_2001/11_rese\%C3\%B1a_4Juan_Pozo.pd

Siboney, V. M. (Diciembre de 2013). Desarrollo de la comprensión lectora del inglés en estudiantes universitarios: una experiencia didáctica. acción $p$ e d a g ó g i c a, $N^{\circ} 22$ / E nero - Diciembre, 2013 pp. 122, 22(1), 122 - 131. Obtenido de https://dialnet.unirioja.es/servlet/articulo?codigo $=6223458$

Y. Castro, A. A. (2017). PERSPECTIVAS PARA LA 
ENSEÑANZA DEL INGLÉS EN LAS INSTITUCIONES DE EDUCACIÓN SUPERIOR EN ECUADOR. Pedagogia. Obtenido de https://www.pedagogia. edu.ec/public/docs/Comision_10/perspectivas_ para_la_ensenanza_del_ingles.pdf

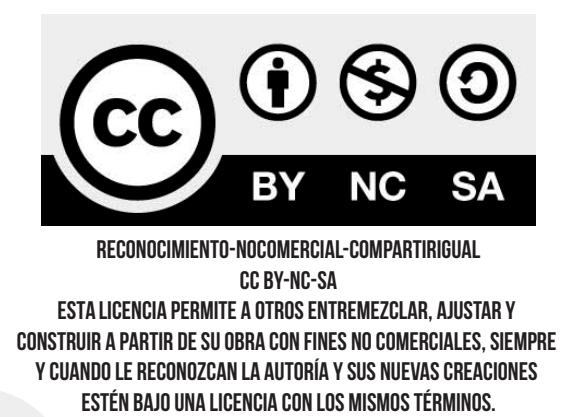

\section{CITAR ESTE ARTICULO:}

Veliz Blacio, J. (2020). Importance of applying operational methodological techniques during the period of teaching - learning English in University undergraduate. RECIMUNDO, 4(2), 195-208. doi:10.26820/recimundo/4.(2). mayo.2020.195-208 